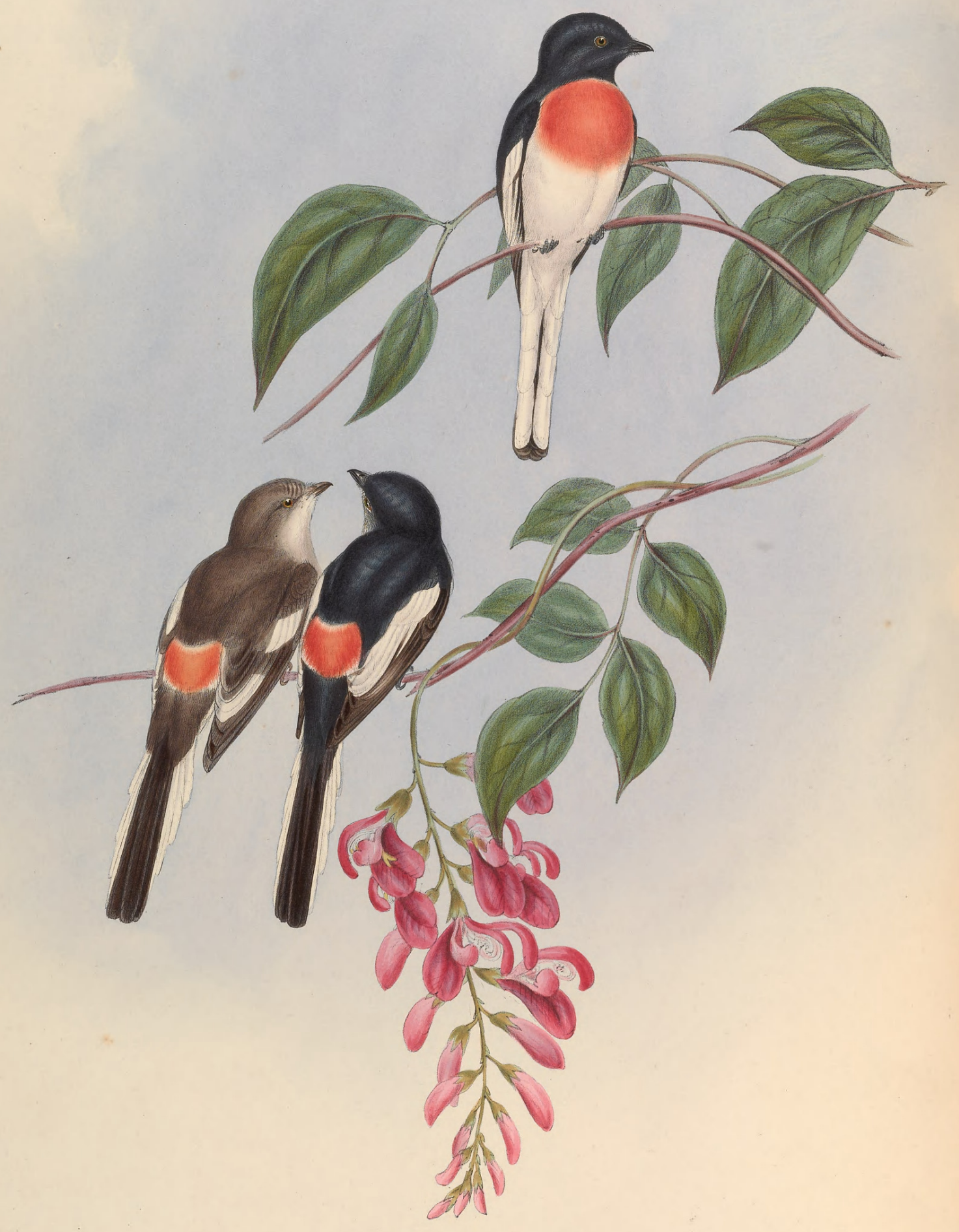

PFRICROCOTTS ERYTHRDPYGITS. 


\section{PERICROCOTUS ERYTHROPYGIUS.}

\section{Cawnpore Pericrocotus.}

Turdus speciosus, var. B. Lath. Gen. Hist., vol. v. p. 97 ?

Cawnpore Flycatcher, Lath. Gen. Hist., vol. vi. p. 176. pl. xcviii*.

Muscicapa erythropygia, Jerd. Madras Journ. of Lit. and Sci., vol. xi. p. 17.

Pericrocotus erythropygius, Blyth, Journ. Asiat. Soc. Beng., vol. xv. p. 310.-Jard. Contrib. Orn., 1848, pl. 1.— Blyth, Cat. of Birds in Mus. Asiat. Soc. Calcutta, p. 193.-Gray and Mitch. Gen. of Birds, vol. i. p. 282, Pericrocotus, sp. 10 .

Fon the original description of this bird we must refer to the "General History" of Latham, where it is described and figured under the name of Cawnpore Flycatcher. The merit of assigning to it a distinctive appellation is due to Mr. T. C. Jerdon of Madras, in whose paper on the "Birds of the Peninsula of India" it is characterized as Muscicapa erythropygia. The descriptions and figure above referred to were the only evidence on record of the existence of the species until the year 1847, when several specimens were brought to this country in the fine collection of Indian Birds formed by Captain W. J. Boys of the Madras Light Cavalry, in the Upper Gangetic provinces of India; which specimens now form part of the collection of Dr. T. B. Wilson, at Philadelphia, that of H. E. Strickland, Esq., and of my own.

It is in every respect a true Pericrocotus, but differs from the other members of the genus in its colouring ; a difference however which can only be regarded as specific, since in form it is precisely similar.

Latham states that it is found at Cawnpore in July; Mr. Jerdon met with it once only, " in the low and thick jungle on the top of the ghauts near Ajunteh ;" and Captain Boys procured examples in the Nerbudda Valley below Jaum Ghat and among the hills on the table-land near Mhow, also at Suckteys-ghur on the 4 th of June. It is very sprightly in its manners, frequents bushes and copse wood, utters a little pink-pink when taking flight and occasionally when hopping among the trees, an isd generally seen in small flocks of three or four pairs. Mr. Blyth gives Hindostan as its habitat, but adds that it does not frequent Lower Bengal.

The male has the whole of the head, throat, back, wing and upper tail-coverts, glossy blue-black; under surface and the tips of the lateral tail-feathers white; band crossing the lower part of the back and a large spot on the breast pale vermilion; the coverts of the secondaries and the outer portion of the tertiaries white, forming a longitudinal mark down the wing; primaries and secondaries black, becoming paler at the tip, the fifth and sixth primaries and the secondaries largely marked with white at the base; bill and legs black ; irides light brown.

The female has the throat and all the under parts white; upper surface brown where the male is black; tail as in the male, but brown instead of black; a band of scarlet across the rump, but not so bright as in the other sex.

The Plate represents two males and a female of the natural size, on the branch of Cyrtotropis carnea. 


\section{$2 \mathrm{BHL}$ Biodiversity Heritage Library}

Gould, John. 1850. "Cawnpore Pericrocotus, Pericrocotus erythropygius [PI. 6]." The Birds of Asia 2(I), -. https://doi.org/10.5962/p.323428.

View This Item Online: https://www.biodiversitylibrary.org/item/118636

DOI: https://doi.org/10.5962/p.323428

Permalink: https://www.biodiversitylibrary.org/partpdf/323428

\section{Holding Institution}

Smithsonian Libraries

\section{Sponsored by}

Smithsonian Institution Libraries

\section{Copyright \& Reuse}

Copyright Status: Not in copyright

This document was created from content at the Biodiversity Heritage Library, the world's largest open access digital library for biodiversity literature and archives. Visit BHL at https://www.biodiversitylibrary.org. 